\title{
Nitrous Oxide Reduction Activity of Denitrifying Ochrobactrum anthropi Isolated from Rice Field
}

\author{
RATNA SETYANINGSIH ${ }^{1}$, IMAN RUSMANA ${ }^{2}$, PRIHASTO SETYANTO $^{3}$, \\ AND ANTONIUS SUWANTO²
}

\author{
${ }^{1}$ Department of Biology, Faculty of Mathematics and Natural Sciences, Universitas Sebelas Maret, Jalan Ir Sutami $36 \mathrm{~A}$ \\ Kentingan, Surakarta 57126, Indonesia; \\ ${ }^{2}$ Department of Biology, Faculty of Mathematics and Natural Sciences, Institut Pertanian Bogor, \\ Darmaga Campus, Bogor 16680, Indonesia; \\ ${ }^{3}$ Balai Penelitian Lingkungan Pertanian, Jalan Jakenan-Jaken Km 05, Jakenan, Pati 59182, Indonesia
}

\begin{abstract}
Nitrous oxide $\left(\mathrm{N}_{2} \mathrm{O}\right)$ is one of the principal greenhouse gases. Differences in soil microbial community composition affect $\mathrm{N}_{2} \mathrm{O}$ emission. Ochrobactrum anthropi $\mathrm{BL} 1$ and $\mathrm{BLN} 1$ isolated from rice field in Tangerang, Banten, Indonesia can grow on and reduce $\mathrm{N}_{2} \mathrm{O}$. This study investigated the patterns of $\mathrm{N}_{2} \mathrm{O}$ reduction activity and growth of $O$. anthropi $\mathrm{BL} 1$ and BLN1 on denitrification media and also examined the ability of BLN1 strain to reduce $\mathrm{N}_{2} \mathrm{O}$ in flooded rice soil. Nitrous oxide reduction activity and growth of strains BL1 and BLN1 occurred simultaneously, indicating that the bacteria used $\mathrm{N}_{2} \mathrm{O}$ for growth. BL1 and BLN1 showed the same specific growth rate, but the $\mathrm{N}_{2} \mathrm{O}$ reduction rate of $\mathrm{BLN} 1$ was higher than that of $\mathrm{BL} 1$. Increase of the $\mathrm{N}_{2} \mathrm{O}$ concentration in the surface water of flooded soil without BLN1 isolate six hours after the addition of $\mathrm{NO}_{3}^{-}$was significantly greater than the surface water from soil that had been inoculated with the isolate.
\end{abstract}

Key words: $\mathrm{N}_{2} \mathrm{O}$, Ochrobactrum anthropi, reduction, rice field

Dinitrogen oksida $\left(\mathrm{N}_{2} \mathrm{O}\right)$ merupakan salah satu gas rumah kaca utama. Perbedaan komposisi komunitas mikrobia dalam tanah mempengaruhi emisi $\mathrm{N}_{2} \mathrm{O}$. Ochrobactrum anthropi BL1 dan BLN1 yang diisolasi dari sawah di daerah Tangerang, Banten, Indonesia dapat tumbuh dengan mereduksi $\mathrm{N}_{2} \mathrm{O}$. Penelitian ini mengkaji pola pertumbuhan dan aktivitas reduksi $\mathrm{N}_{2} \mathrm{O}$ dari $O$. anthropi $\mathrm{BL} 1$ dan BLN1 dalam media denitrifikasi serta kemampuan galur BLN1 mereduksi $\mathrm{N}_{2} \mathrm{O}$ di tanah sawah tergenang. Aktivitas reduksi $\mathrm{N}_{2} \mathrm{O}$ dan pertumbuhan galur BL1 dan BLN1 berlangsung serentak, menunjukkan bahwa bakteri menggunakan $\mathrm{N}_{2} \mathrm{O}$ untuk tumbuh. Nilai kecepatan pertumbuhan spesifik antara BL1 dengan BLN1 sama, sedangkan kecepatan reduksi $\mathrm{N}_{2} \mathrm{O}$ galur BLN1 lebih tinggi dari pada BL1. Peningkatan konsentrasi $\mathrm{N}_{2} \mathrm{O}$ dalam air permukaan tanah tergenang setelah enam jam penambahan $\mathrm{NO}_{3}{ }^{-}$di tanah tanpa isolat BLN1 lebih besar secara signifikan dari pada di tanah yang ditambah isolat.

Kata kunci: $\mathrm{N}_{2} \mathrm{O}$, Ochrobactrum anthropi, reduksi, sawah

Denitrification is defined as the dissimilatory reduction of nitrate $\left(\mathrm{NO}_{3}^{-}\right)$, or nitrite $\left(\mathrm{NO}_{2}^{-}\right)$to nitrous oxide $\left(\mathrm{N}_{2} \mathrm{O}\right)$ or nitrogen gas $\left(\mathrm{N}_{2}\right)$ (Hayatsu et al. 2008). Denitrification is part of the bioenergetic apparatus of bacterial cell. The complete denitrification leads to $\mathrm{N}_{2}$ formation while the incomplete process produces $\mathrm{N}_{2} \mathrm{O}$ (Zumft 1997). Nitrous oxide is one of the principal greenhouse gases. Concentration of $\mathrm{N}_{2} \mathrm{O}$ in the atmosphere increased from 270 in pre-industrial era to $319 \mathrm{ppb}$ in 2005 . The primary driver of $\mathrm{N}_{2} \mathrm{O}$ increase is microbial production in expanding and fertilized agricultural land (Forster and Ramaswamy 2007). Differences in soil microbial community composition affect $\mathrm{N}_{2} \mathrm{O}$ emission (Holtan-Hartwig 2000).

The species Ochrobactrum anthropi was described

\footnotetext{
*Corresponding author; Phone/Fax: +62-271-663375,
} Email: ratnasetya@yahoo.co.id first by Holmes et al. (1988) as the sole species of Ochrobactrum. Since then, some other species of Ochrobactrum had been discovered (Kämpfer et al. 2007). O. anthropi is a Gram negative, rod shaped, motile, and obligately aerobic bacteria (Holmes et al. 1988). O. anthropi are widely distributed in diverse habitat including human body (Holmes et al. 1988), activated sludge taken from reclaimed land (Song et al. 2002), rice field water (Reche and Fiuza 2005), and wastewater treatment plant (Zuo et al. 2008). Some $O$. anthropi strains have been identified as denitrifier (Sung et al. 2002; Doi et al. 2009). Nevertheless, $\mathrm{N}_{2} \mathrm{O}$ reduction activities of these strains have not been investigated.

Setyaningsih et al. (2010) reported that $O$. anthropi BL1 and BLN1 could grow on $\mathrm{N}_{2} \mathrm{O}$ as a sole electron acceptor. In 5 days, BL1 and BLN1 reduced $\mathrm{N}_{2} \mathrm{O}$ up to 


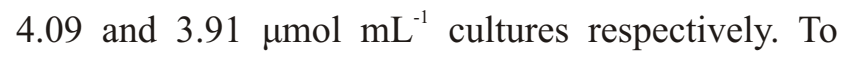
confirm and further characterize $\mathrm{N}_{2} \mathrm{O}$ reduction capacity of the isolates, this study investigated the patterns of $\mathrm{N}_{2} \mathrm{O}$ reduction activity and growth of $O$. anthropi BL1 and BLN1 on denitrification media. This study also examined the ability of BLN1 strain to reduce $\mathrm{N}_{2} \mathrm{O}$ in flooded rice soil. $\mathrm{N}_{2} \mathrm{O}$ reducing denitrifier maybe able to be used as $\mathrm{N}_{2} \mathrm{O}$ emission controller in rice field.

\section{MATERIALS AND METHODS}

Bacterial Strains and Media. The bacterial strains used in this study were isolated from rice field in Tangerang, Banten, Indonesia and have been characterized previously (Setyaningsih et al. 2010). Experiments were conducted using denitrification media containing $\mathrm{CH}_{3} \mathrm{COONa} \cdot 3 \mathrm{H}_{2} \mathrm{O} 2.72 \mathrm{~g} \mathrm{~L} \mathrm{~L}^{-1}$, $\mathrm{K}_{2} \mathrm{HPO}_{4} 0.80 \mathrm{~g} \mathrm{~L}^{-1}, \mathrm{KH}_{2} \mathrm{PO}_{4} 0.30 \mathrm{~g} \mathrm{~L}^{-1}, \mathrm{NH}_{4} \mathrm{Cl} 0.40 \mathrm{~g} \mathrm{~L}^{-1}$, $\mathrm{MgSO}_{4} \cdot 7 \mathrm{H}_{2} \mathrm{O} 0.40 \mathrm{~g} \mathrm{~L}^{-1}$ (Barford et al. 1999), and yeast extract $3 \mathrm{~g} \mathrm{~L}^{-1}$.

Soil. Soil samples were obtained from the top 20 $\mathrm{cm}$ of a paddy field. The soil was air-dried, broken up, sieved $(2 \mathrm{~mm})$ and thoroughly mixed. The particle size distribution was $51 \%$ clay, $34 \%$ silt, and $15 \%$ sand.

Nitrous Oxide Reduction Activity and Bacterial Growth Patterns. $\mathrm{N}_{2} \mathrm{O}$ reduction activity and bacterial growth patterns on denitrification media were observed using $\mathrm{N}_{2} \mathrm{O}$ as a sole terminal electron acceptor. Experiments were carried out in anaerobic condition with $10.1 \mathrm{~mL}$ sterile media in the $20.1 \mathrm{~mL}$ test tubes with rubber stoppers. Media were flushed with $\mathrm{N}_{2}$ for 10 minutes. $\mathrm{N}_{2} \mathrm{O}$ was injected into each test tube. $\mathrm{N}_{2} \mathrm{O}$ concentration dissolved in the media at the beginning of the experiment was $12.75 \mathrm{mM}$. Inoculum was prepared by anaerobic growth in media supplemented with $\mathrm{NaNO}_{3}\left(1.275 \mathrm{~g} \mathrm{~L}^{-1}\right)$. Cells from exponential phase inoculum culture were twice washed by centrifugation in sterile distilled water and resuspended in fresh media without $\mathrm{NO}_{3}$. After inoculation, cultures were incubated at $30{ }^{\circ} \mathrm{C}$ with rolling. Periodically, $\mathrm{N}_{2} \mathrm{O}$ were sampled from the headspace of test tubes by gas-tight syringes and measured by gas chromatography with a Shimadzu 14A ECD gas chromatograph equipped with Q Porapak column. Carrier gases were methane (5\%) and argon (95\%) and the operating temperatures were as follows; detector $340^{\circ} \mathrm{C}$, column $35^{\circ} \mathrm{C}$, injector $200^{\circ} \mathrm{C}$. Growth of bacteria was monitored based on the culture's turbidity using nephelometer EEL Unigalvo DS29.

$\mathrm{N}_{2} \mathrm{O}$ concentration in solution was calculated with the formula: $y=\alpha^{*} x$ (solution volume/headspace volume), where $y$ was amount of the dissolved $\mathrm{N}_{2} \mathrm{O}$ $(\mu \mathrm{mol})$ in a closed system, $\alpha$ was solubility of $\mathrm{N}_{2} \mathrm{O}$ expressed as dissolved $\mathrm{N}_{2} \mathrm{O}\left(\mathrm{mL} \mathrm{N}_{2} \mathrm{O} \mathrm{mL}^{-1} \mathrm{H}_{2} \mathrm{O}\right)$, and $x$ was amount of $\mathrm{N}_{2} \mathrm{O}$ in the flask headspace $(\mu \mathrm{mol})$ (Carter 1993). The specific growth rate was calculated with the formula $\mu=(\Delta \ln N) / \Delta t$, where $N$ was the cells number per milliliter and $t$ was the corresponding time (hours) (El Hassan et al. 1985). Reduction rate of $\mathrm{N}_{2} \mathrm{O}$ $\left(v_{\text {red }}\right)$ was calculated by the analogous equation $v_{\text {red }}=$ $\Delta S / \Delta t$ where $S$ was dissolved $\mathrm{N}_{2} \mathrm{O}$ concentration.

$\mathrm{N}_{2} \mathrm{O}$ Reduction in Rice Soil. $\mathrm{N}_{2} \mathrm{O}$ reduction in rice soil experiment was carried out using rice soil flooded with distilled water in close system. Two hundreds and twenty grams of soil was filled into the $603 \mathrm{~mL}$ bottle with rubber stopper. Soil thickness in the bottle was 6 $\mathrm{cm}$. Soil was flushed with $\mathrm{N}_{2}$ for $15 \mathrm{~min}$ to minimize the residual $\mathrm{NO}_{3}{ }_{3}^{-}$and incubated for $2 \mathrm{~d}$. Flushing the soil with $\mathrm{N}_{2}$ was repeated to remove the $\mathrm{N}_{2} \mathrm{O}$ that might have been produced from residual $\mathrm{NO}_{3}$. Distilled water was added up to $2 \mathrm{~cm}$ above the soil surface. The flooded soil was incubated for $7 \mathrm{~d}$ with the bottle cap opened to mimic the rice field condition. The soil $\mathrm{pH}$ was measured. 0.6 mmol $\mathrm{NO}_{3}{ }^{-}$was added as $\mathrm{NaNO}_{3}{ }^{-} . O$. anthropi BLN1 inoculum was added as suspension in sterile distilled water $\left(5 \times 10^{8} \mathrm{CFU}\right)$. After $\mathrm{NO}_{3}{ }^{-}$and inoculum addition, the bottle was closed with rubber stopper. Control was prepared without bacterial inoculum. The headspace gas was sampled every $3 \mathrm{~h}$ to determine $\mathrm{N}_{2} \mathrm{O}$ concentration. After gas sampling from the headspace, bottle cap was opened. Surface water sample for dissolved $\mathrm{N}_{2} \mathrm{O}$ analysis was taken using syringe and transferred into test tube containing $100 \mu \mathrm{L}$ of formaldehyde $(38 \%(\mathrm{v} / \mathrm{v}))$ and capped with rubber stopper. Water samples in the test tubes were shaken vigorously and $\mathrm{N}_{2} \mathrm{O}$ concentration in the headspace was measured using Shimadzu 14A ECD gas chromatograph with Q Porapak column. Carrier gas used was $\mathrm{N}_{2}$ and the operating temperatures were as follows; detector $350{ }^{\circ} \mathrm{C}$, column $60{ }^{\circ} \mathrm{C}$, and injector $150{ }^{\circ} \mathrm{C}$. The emission value was calculated by subtracting the $\mathrm{N}_{2} \mathrm{O}$ concentration in the headspace at the certain time by the initial $\mathrm{N}_{2} \mathrm{O}$ concentration .

\section{RESULTS}

Nitrous Oxide Reduction Activity and Bacterial Growth. Fig 1 reported the $\mathrm{N}_{2} \mathrm{O}$ reduction activity and growth of BL1 and BLN1 bacterial strains. The slopes of curves indicate the specific growth rate $(\mu)$ and $\mathrm{N}_{2} \mathrm{O}$ reduction rate $\left(v_{\text {red }}\right)$ (Table 1). BL1 and BLN1 strains showed the same $\mu$. However BLN1's $v_{\text {red }}$ was higher 

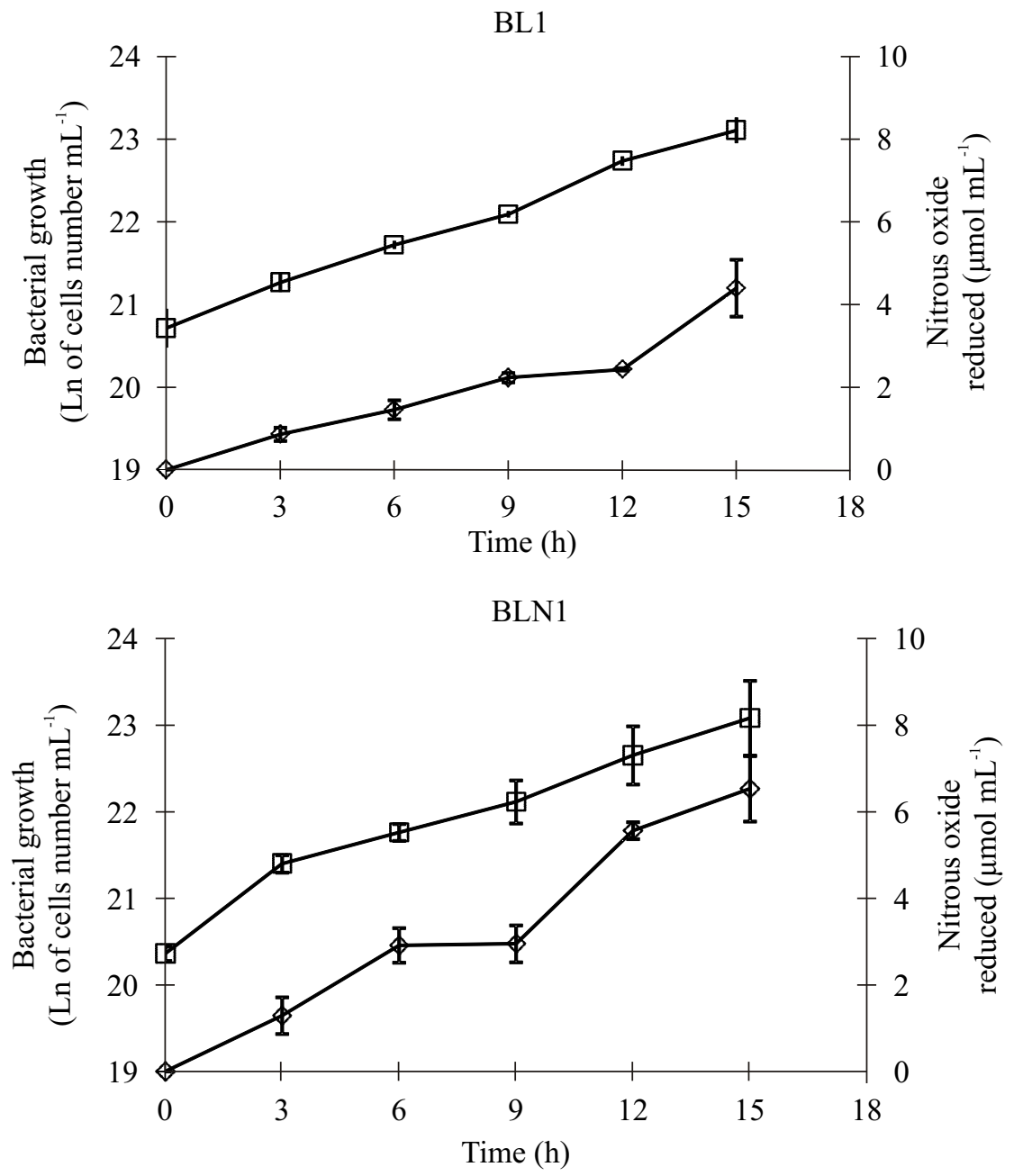

Fig 1 Nitrous oxide reduction activity and bacterial growth of strains BL1 and BLN1. Bars represent standard error, calculated from three experiments. $\square$ :bacterial growth; $\diamond$ :nitrous oxide reduced.

Table 1 Nitrous oxide reduction rate $\left(\mathrm{v}_{\text {red }}\right)$ and specific growth rate $(\mu)$ of strains BL1 and BLN1

\begin{tabular}{lcc}
\hline Strain & $v_{\text {red }}\left(\mu \mathrm{mol} \mathrm{mL} \mathrm{m}^{-1} \mathrm{~h}^{-1}\right) \pm \mathrm{SE}$ & $\mu\left(\mathrm{h}^{-1}\right) \pm \mathrm{SE}$ \\
\hline BL1 & $0.26 \pm 0.03$ & $0.17 \pm 0.02$ \\
BLN1 & $0.43 \pm 0.03$ & $0.17 \pm 0.03$
\end{tabular}

SE: standard error.

than BL1's. The $\mu: v_{\text {red }}$ ratio of strains BL1 and BLN1 were 0.65 and 0.45 , respectively. This ratio expresses the efficiency of each bacterial strain in utilizing $\mathrm{N}_{2} \mathrm{O}$ as electron acceptor.

Nitrous Oxide Emission from Rice Soil. The amount of $\mathrm{N}_{2} \mathrm{O}$ in the headspace of bottle filled with rice soil at the beginning of experiment was $6.86 \mathrm{nmol}$. There was the fluctuation of the amount of $\mathrm{N}_{2} \mathrm{O}$ in the headspace during $9 \mathrm{~h}$ observation (Fig 2). Nevertheless, the $\mathrm{N}_{2} \mathrm{O}$ emission did not show any significant difference between soil incubated with BLN1 strain or without bacterial strain after 3, 6, and 9 $\mathrm{h}$ of incubation (Table 2). The concentration of $\mathrm{N}_{2} \mathrm{O}$ in the surface water at the beginning of the treatment was $0.70 \mathrm{nmol} \mathrm{L}^{-1}$. The concentration of $\mathrm{N}_{2} \mathrm{O}$ in the surface water increased sharply for $6 \mathrm{~h}$ following the addition of $\mathrm{NO}_{3}^{-}$in soil without isolate. However, the concentration started to go down after $6 \mathrm{~h}$ of incubation (Fig 3). Increase of the concentration of $\mathrm{N}_{2} \mathrm{O}$ in the surface water of flooded soil after incubation was significantly greater for soil without BLN1 isolate than soil with the addition of isolate (Table 3 ).

\section{DISCUSSION}

Nitrous oxide reduction activity and growth of 


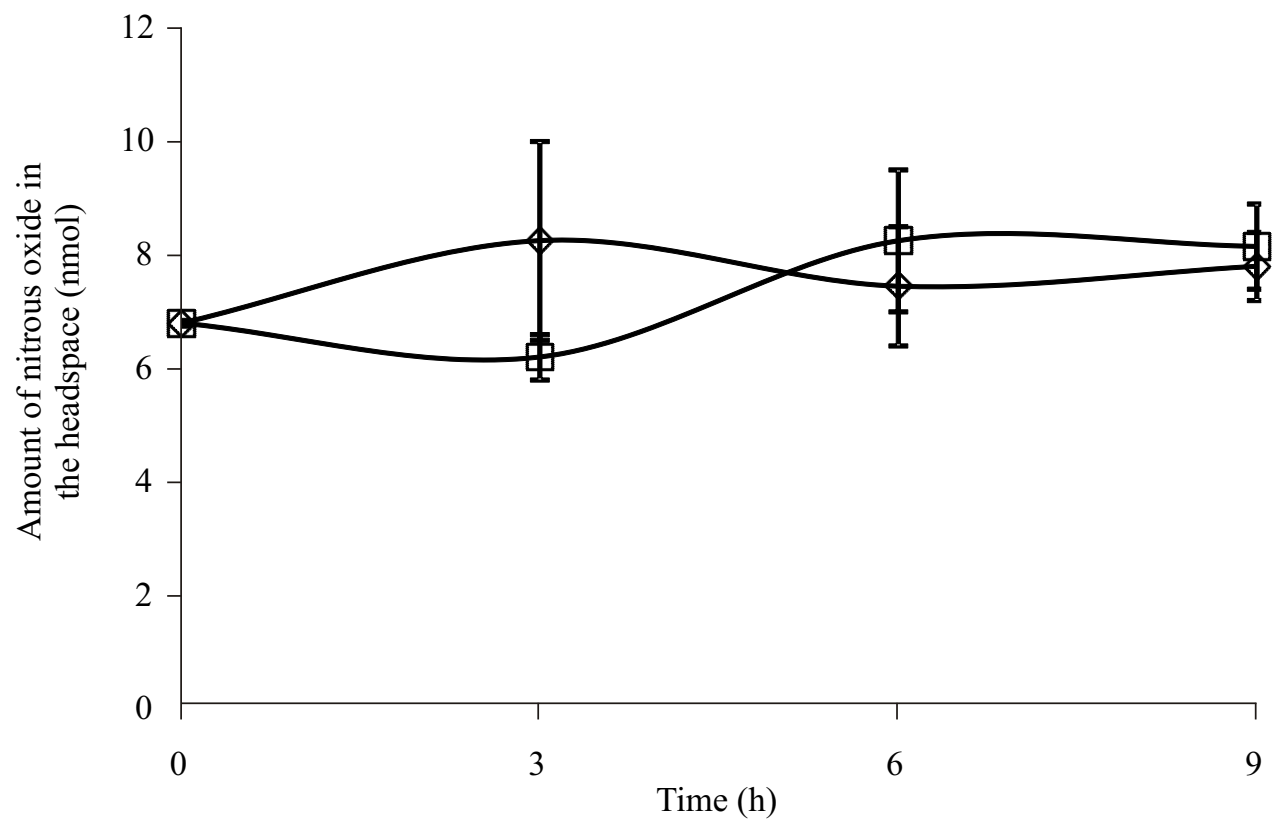

Fig 2 Amount of $\mathrm{N}_{2} \mathrm{O}$ in the headspace without and with BLN1 inoculation following the addition of $0.6 \mathrm{mmol}^{-} \mathrm{NO}_{3}^{-}$. Bars represent standard error. $\square$ :without isolate; $\diamond$ :with isolate.

Table 2 Emission of $\mathrm{N}_{2} \mathrm{O}$ with and without BLN1 inoculation following the addition of 0.6 mmol of $\mathrm{NO}_{3}$

\begin{tabular}{ccc}
\hline Time $(\mathrm{h})$ & Without isolate $\left(\mathrm{nmol} \mathrm{m}^{-2}\right)$ & With isolate $\left(\mathrm{nmol} \mathrm{m}^{-2}\right)$ \\
\hline 3 & $0.30 \mathrm{a}$ & $-0.11 \mathrm{a}$ \\
6 & $0.12 \mathrm{a}$ & $0.29 \mathrm{a}$ \\
9 & $0.20 \mathrm{a}$ & $0.28 \mathrm{a}$ \\
\hline
\end{tabular}

All of the numbers followed by the same alphabet indicates no significant difference in the analysis of variance with $\alpha=0.05$.

strains BL1 and BLN1 occurred simultaneously, indicating that the bacteria used $\mathrm{N}_{2} \mathrm{O}$ for growth. $O$. anthropi BL1 and BLN1 had high ability to grow on and reduce $\mathrm{N}_{2} \mathrm{O}$. They grew well for $15 \mathrm{~h}$ on $\mathrm{N}_{2} \mathrm{O}$. Snyder et al. (1987) found that Pseudomonas aeruginosa $\mathrm{PAO} 1$ and $\mathrm{P} 1$ lost the ability to grow on $\mathrm{N}_{2} \mathrm{O}$ after 1-3 $\mathrm{h}$ due to the loss of $\mathrm{N}_{2} \mathrm{O}$ uptake activity. P. aeruginosa $\mathrm{P} 2$ also exhibited a loss of $\mathrm{N}_{2} \mathrm{O}$ uptake activity but the loss was not as extensive as strains $\mathrm{PAO} 1$ and P1. P2 could still grew at slower rate until $\mathrm{N}_{2} \mathrm{O}$ became exhausted after $8 \mathrm{~h}$. Synthesis and destruction of enzyme could control $\mathrm{N}_{2} \mathrm{O}$ reduction activity in denitrification bacteria. Bacterial strains having the ability to reactivate or synthesize new enzyme could grow longer on $\mathrm{N}_{2} \mathrm{O}$.

The increase of $\mathrm{N}_{2} \mathrm{O}$ in the surface water for $6 \mathrm{~h}$ following the addition of $0.6 \mathrm{mmol} \mathrm{NO}_{3}$ indicated an $\mathrm{NO}_{3}^{-}$reduction activity of denitrifying bacteria in the flooded soil. The reduction of $\mathrm{NO}_{3}^{-}$could be done by the native denitrifiers and the inoculants. Nevertheless addition of the inoculants increased the activity of $\mathrm{N}_{2} \mathrm{O}$ reduction. The concentration of $\mathrm{N}_{2} \mathrm{O}$ in the surface water of flooded soil decreased after six h of incubation since $\mathrm{N}_{2} \mathrm{O}$ went through further reduction to become $\mathrm{N}_{2}$. In spite of the increasing $\mathrm{N}_{2} \mathrm{O}$ concentration in the surface water of flooded soil without isolate at the sixth hour, $\mathrm{N}_{2} \mathrm{O}$ released into the headspace did not go through any significant rise, then. According to Heincke and Kaupenjohan (1999), the speed of $\mathrm{N}_{2} \mathrm{O}$ dissolving in the water and escaping into the atmosphere depended, among others, on the turbulence and the speed of water current. If there was a current with sufficient aeration, then the dissolved $\mathrm{N}_{2} \mathrm{O}$ would go in to the atmosphere in several min. If $\mathrm{N}_{2} \mathrm{O}$ stayed in the ground water sufficiently long then there would be sufficient time for $\mathrm{N}_{2} \mathrm{O}$ to be reduced to $\mathrm{N}_{2}$.

BLN1 strain is expected to maintain its high ability to reduce $\mathrm{N}_{2} \mathrm{O}$ in the environment among the bacterial community. BLN1 strain could use $\mathrm{NO}_{3}^{-}, \mathrm{NO}_{2}^{-}$, and $\mathrm{O}_{2}$ (Setyaningsih 2011) in addition to $\mathrm{N}_{2} \mathrm{O}$ as the terminal electron acceptor so that its sustainibility in the environment could be supported. According to Martin 


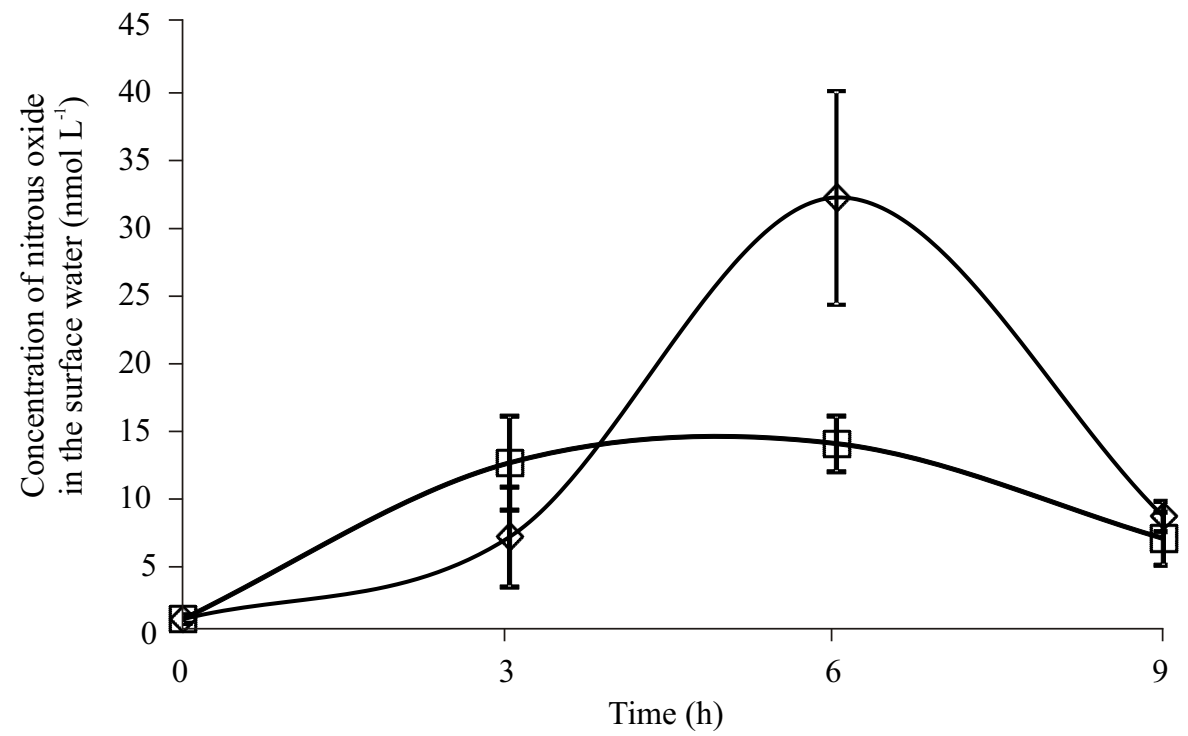

Fig 3 Concentration of $\mathrm{N}_{2} \mathrm{O}$ in the suface water without and with $\mathrm{BLN} 1$ inoculation following the addition of $0.6 \mathrm{mmol}^{\circ} \mathrm{NO}_{3}^{-}$ Bars represent standard error. $\square$ :without isolate; $\diamond$ :with isolate.

Table 3 Increase of the concentration of $\mathrm{N}_{2} \mathrm{O}$ in the surface water with and without BLN1 inoculation following the addition of $0.6 \mathrm{mmol} \mathrm{NO}_{3}$

\begin{tabular}{ccc}
\hline Time $(\mathrm{h})$ & Without isolate $\left(\mathrm{nmol} \mathrm{m}^{-2}\right)$ & With isolate $\left(\mathrm{nmol} \mathrm{m}^{-2}\right)$ \\
\hline 3 & $6.07 \mathrm{a}$ & $11.53 \mathrm{a}$ \\
6 & $31.12 \mathrm{~b}$ & $12.94 \mathrm{a}$ \\
9 & $7.59 \mathrm{a}$ & $5.95 \mathrm{a}$
\end{tabular}

All of the numbers followed by the same alphabet indicates no significant difference in the analysis of variance followed by Duncan's multiple range test with $\alpha=0.05$.

et al. (1988) the population of denitrifying bacteria had persistent and stable characteristics. In conclusion, our results seems to indicate that the BLN1 strain could be used to reduce the emission of $\mathrm{N}_{2} \mathrm{O}$ from the rice fields.

\section{ACKNOWLEDGMENT}

This research was supported by BPPS scholarship grant from DIKTI to the first author. Thanks also due to DB Nedwell, emeritus professor of Department of Biological Sciences, University of Essex, Colchester, United Kingdom for his great support and advice.

\section{REFERENCES}

Barford CC, Montoya JP, Altabet MA, Mitchell R. 1999. Steady-state nitrogen isotope effects of $\mathrm{N}_{2}$ and $\mathrm{N}_{2} \mathrm{O}$ production in Paracoccus denitrificans. Appl Environ Microbiol. 65(3): 989-994.

Carter MR, editor. 1993. Soil sampling methods of analysis. Boca Raton: CRC Press LLC Lewis Publisher. p 354.

Doi Y, Takaya N, Takizawa, N. 2009. Novel denitrifying bacterium Ochrobactrum anthropi YD50.2 tolerates high levels of reactive nitrogen oxide. Appl Environ Microbiol. 75(16):5186-5194. doi:10.1128/AEM.0060409.

El Hassan GA, Zablotowicz RM, Focht DD. 1985. Kinetics of denitrifying growth by fast-growing cowpea Rhizobia. Appl Environ Microbiol. 49(3): 517-521.

Forster P, Ramaswamy V. 2007. Change in atmospheric constituents and radiative forcing. In: Solomon, S et al., editor. Climate Change 2007: The Physical Science Basis. Contribution of Working Group I to The Fourth Assesment Report of The Intergovernmental Panel on Climate Change. Cambridge: Cambridge University Press. p 130-217.

Hayatsu M, Tago K, Saito M. 2008. Various players in the nitrogen cycle: diversity and functions of the microorganisms involved in nitrification and denitrification. Soil Sci Plant Nutr. 54(1):33-45. doi:10.1111/j.1747-0765.2007.00195.x

Heincke M, Kaupenjohann M. 1999. Effect of solution on the dynamics of $\mathrm{N}_{2} \mathrm{O}$ emissions: a review. Nutr $\mathrm{Cycl}$ Agroecosyst. 55(2):133-157. doi:10.1023/A:10098420 11599.

Holmes B, Popoff M, Kiredjian M, Kersters K. 1988. Ochrobactrum anthropi gen. nov. from human clinical 
specimen and previously known as group Vd. Int J Syst Bacteriol. 38(4):406-416.

Holtan-Hartwig L, Dörsch P, Bakken LR. 2000. Comparison of denitrifying communities in organic soils: kinetics of $\mathrm{NO}_{3}{ }^{-}$and $\mathrm{N}_{2} \mathrm{O}$ reduction. Soil Biol Biochem. 32(6):833843.

Kampfër P, Citron DM, Goldstein EJC, Scholz HC. 2007. Difficulty in the identification and differentiation of clinically relevant Ochrobactrum species. J Med Microbiol. 56(11): 1571-1573. doi:10.1099/jmm.0.473 $50-0$.

Martin K, Parsons LL, Murray RE, Smith MS. 1988. Dynamics of soil denitrifier populations: relationships between enzyme activity, most-probable-number counts and actual N gas loss. Appl Environ Microbiol. 54(11):2711-2716.

Reche MHLR, Fiuza LM. 2005. Bacterial diversity in ricefield water in Rio Grande Do Sul. Braz J Microbiol. 36(3):253-257. doi:10.1590/S1517-838220050003000 09.

Setyaningsih R. 2011. Karakterisasi dan uji aktivitas bakteri denitrifikasi pereduksi dinitrogen oksida $\left(\mathrm{N}_{2} \mathrm{O}\right)$ yang diisolasi dari tanah sawah [Characterization and nitrous oxide $\left(\mathrm{N}_{2} \mathrm{O}\right)$ reduction activity of denitrifying bacteria isolated from rice field] [dissertation]. Bogor (ID): Institut Pertanian Bogor.
Setyaningsih R, Rusmana I, Setyanto P, Suwanto A. 2010. Physiological characterization and molecular identification of denitrifying bacteria possesing high nitrous oxide reduction activity isolated from rice soils. Microbiol Indones. 4(2):75-79. doi: 10.5454/mi.4.2.5.

Snyder SW, Bazylinski DA, Hollocher TC. 1987. Loss of $\mathrm{N}_{2} \mathrm{O}$ reductase activity as an explanation for poor growth of Pseudomonas aeruginosa on $\mathrm{N}_{2} \mathrm{O}$. Appl Environ Microbiol. 53(9):2045-2049.

Song SH, Yeom SH, Choi SS, Yoo YJ. 2002. Effect of aeration on denitrification by Ochrobactrum anthropi SY509. Biotechnol Bioprocess Eng. 7(6):352-356.

Sung DW, Song SH, Kim JH, Yoo YJ. 2002. Effects of electron donors on nitrate removal by nitrate and nitrite reductases. Biotechnol Bioprocess Eng. 7(2):112-116.

Zumft WG. 1997. Cell biology and molecular basis of denitrification. Microbiol Mol Biol Rev. 61(4):533616.

Zuo Y, Xing D, Regan JM, Logan BE. 2008. Isolation of the exoelectrogenic bacterium Ochrobactrum anthropi YZ-1 by using u-tube microbial fuel cell. Appl Environ Microbiol. 74(10):3130-3137. doi:10.1128/AEM.0273 2-07. 